scientifique, qui possèderait son équipement propre et appointerait un personnel uniquement consacré à la recherche tant dans le domaine des sciences pures que dans celui de leurs applications. Cet Institut aurait également dans ses attributions d'aider des chercheurs non appointés par lui, par exemple en leur fournissant de la documentation, ou par l'octroi de subsides, ou par le prêt d'instruments, ou encore en les invitant à venir travailler dans les locaux de l'Institut. Ces projets sont ambitieux. Néanmoins, la commission tente d'établir quelles doivent être les grandes lignes de l'organisation d'une pareille entreprise. . . . (Docteur I. Vincke dans Belgique d'Outre-mer, Oct. 1945.)

\title{
African Studies in Spain
}

Br a decree signed by the Head of the State, Señor Franco, on 28 June 1945, an Institute of African Studies (I.D.E.A.) was established in Spain, with head-quarters in Madrid. Its principal object is to promote scientific investigations in Spanish Africa; and it will also, when requested, give advice on scientific questions to government departments, organize and direct courses of study for administrative candidates, and spread abroad knowledge of Africa. Working in close association with the Colonial Office (Dirección General de Marruecos y Colonias) and the High Council of Scientific Inquiries, the Institute is to be managed by a Junta composed of a director, a vice-director, members representing scientific societies and others representing the African territories.

Writing in our Spanish namesake, Africa, Professor Julian San Valero remarks that for some time now people in Spain have been talking africanismo with a reiteration never known before. He recalls the part that Spanish scholars took in the Dakar conference of I945, and tells of the Committee that has been set up in Spain, as part of the organization of the International Conference of West Africanists (C.I.A.O.) to prepare for the meeting that is to be held later this year at Accra. The Director General of Morocco and the Colonies, Don José Diaz de Villegas, has shown great interest in this movement. What the relation of this committee is to be to the new Institute is not stated, but, as we are informed by Señor Santa Olalla, it was in consequence of steps taken by him after the Dakar Conference that the Government approved of setting up the Institute. Members of our Institute will welcome Spanish collaboration in africanismo.

\section{Survival of African Culture in America}

ErHNologists in the United States are divided on this subject. One school holds that when Africans were transported into slavery they left behind them everything but their dark skin and tropical temperament; so that among the American Negroes nothing remains of the habits and customs, beliefs and fears, which characterized their African ancestors; and in particular their native languages so completely disappeared that scarcely a word of African origin found its way into American English. On the other hand, investigators like Melville Herskovits contend that considerable cultural elements have survived to this day even where the processes of assimilation have proceeded farthest.

Among the competent observers, Dr. Lorenzo D. Turner of Fisk University stands in the front rank. He studied in London under Dr. Ida Ward, is an expert phonetician and has delved widely into African languages, especially the Sudanic and Bantu languages of the Western regions. For some years now he has investigated the speech of the so-called Gullahs, the Negroes living in the coastal areas of South Carolina and Georgia and in the Sea Islands. He has lived among them, gained their confidence, and made a large number of recordings of their songs, tales and conversations. For the full results of his research we must await the publication of his forthcoming book. In the meantime the American Dialect Society 
has published a paper which outlines some of his findings. It is entitled 'Notes on the Sounds and Vocabulary of Gullah'.

Other investigators (who appear to have been unpractised in phonetics and to have known nothing of African languages) have said that there were few or no African words in Gullah and that words which appeared to be African were really English words strangely transmogrified. Dr. Turner concludes: "Africanisms are still numerous in Gullah. They are found in the sounds, vocabulary, syntax, morphology, and intonation of the dialect, and there are many similarities between Gullah and the African languages in the methods used to form words.' He has collected between five and six thousand African words; approximately four-fifths of these are now used only as personal names; most of the remainder occur daily in conversation. Some words and phrases are heard only in songs and stories; of Dr. Turner's examples 17 are Mende words and $8 \mathrm{Vai}$. He gives a list of twenty-two African languages-ranging from Wolof of Senegal and Gambia to Umbundu of Angola and Luba of Belgian Congo-represented in the Gullah speech. These people appear to follow the African custom of giving their children names which describe some circumstance connected with their birth, the time or place, or their physical condition or temperament, e.g. $A y^{\prime} k u$ is the name given to a boy who is born on Wednesday (Ewe: $A \eta k u$ ); Bumbulu ' a fool' is identical with the Kongo word. We would like to know whether the Gullah know the meaning of all these names or whether the use is merely conventional. The identification of all these words in the African vocabularies must have entailed much patient labour. We shall look forward to Dr. Turner's full exposition of this very interesting research.

\section{The Word 'Bwanga'}

Among the African words found by Dr. Turner in Gullah is Banga which he identifies with the Umbundu and Kimbundu owanga. We recall being asked by a Haitian psychiatrist in what African languages this word occurs. He said that in Haiti it means not the visible form of a 'medicine' but its unseen essence, that which gives 'medicine' its potency. This is precisely the meaning of ubwanga in the minds of the Lambas of Northern Rhodesia: it is (as Dr. C. M. Doke says) 'the power behind the umulaye' (doctor); ' the power for healing or for destroying, for protecting or for hurting '; "umusamu (" medicine ") is the visible form which the unseen ubwanga takes when it is being manipulated by the umulaye'. (The Lambas, p. 290.) This seems to be identical with the Ila concept. Readers of Africa will remember R. J. B. Moore's important article on 'Bwanga among the Bemba' which appeared in vol. xiii, No. 3 (July 1940), in which he said that the Bemba conception of bwanga is very similar to that current among the Ila and Lamba people. 'It is my belief', he wrote, "that if each case of bwanga were thoroughly investigated [by reference to the individual objects which contain it], the names of all ingredients for medicines and charms ascertained together with a statement of the particular associations connected with these objects in the native mind, all bwanga would be self-explanatory; each medicine and charm would be seen to contain its own power by virtue of its inherent nature.' Mr. Moore would not accept any generalization of the bwanga to make it in any way equivalent of mana. In his description of the Kwanyama (Africa, vol. vii, No. 4, October 1934) P. C. Estermann wrote of the omulodi ("warlock, witch') that he or she is "un pauvre innocent accusé de posséder un pouvoir secret et imaginaire - ouanga - qui lui permet de "manger la vie". Ce mot ouanga ne signifie jamais poison.' If we recollect rightly (we cannot give the reference) Baumann found the word among the Tshokwe and interpreted it as zauberkraft. As reported in our January number, p. $5 \mathrm{I}$, bwanga occurs among the Luba as the name of the occult force supposed to be inherent in the rites of the secret society Budye. It is evident there- 